\title{
WORKSHOP METODE GEOLISTRIK RESISTIVITAS UNTUK EKSPLORASI AIR TANAH DI DESA PLANA KECAMATAN SOMAGEDE KAB. BANYUMAS
}

\author{
Sugito $^{\text {1) }}$ Hartono $^{2)}$, Zaroh Irayani ${ }^{3)}$, R. Farzand Abdullatif ${ }^{4)}$ \\ ${ }^{1,2,3,4)}$ Fakultas Matematika dan Ilmu Pengetahuan Alam, Universitas Jenderal Soedirman \\ E-mail: sugito2103@unsoed.ac.id ${ }^{1)}$, hartono@unsoed.ac.id ${ }^{2)}$, zaroh_irayani@yahoo.com ${ }^{3)}$, \\ farzand.abdullatif@gmail.com ${ }^{4)}$
}

\begin{abstract}
Abstrak
Telah dilakukan workshop dalam bentuk kegiatan pembelajaran dan pelatihan metode geolistrik resistivitas untuk eksplorasi air tanah di Desa Plana Kec. Somagede Kab. Banyumas. Tujuan kegiatan adalah meningkatkan pemahaman masyarakat tentang jenis dan pembentukan akuifer, menentukan struktur perlapisan batuan bawah permukaan dan mengidentifikasi akuifer berdasarkan hasil survei geolistrik geolistrik resistivitas konfigurasi Schlumberger. Untuk mencapai tujuan penulis menggunakan metode ceramah dan diskusi interaktif serta workshop metode geolistrik resistivitas. Berdasarkan kegiatan workshop atau pembelajaran dan pelatihan metode geolistrik resistivitas untuk eksplorasi sumber air tanah dapat disimpulkan tingkat antusiasme dan partisipasi peserta workshop sangat tinggi, yaitu rata-rata lebih dari 95 $\%$, struktur perlapisan batuan di Desa Plana berdasarkan nilai resistivitas secara umum terdiri dari tanah penutup (top soil), lempung pasiran, pasir lempungan dan pasir. Sedabgkan jenis akuifer yang telah teridentifkasi titik sounding Sch-1 pada kedalaman $\geq 6,61 \mathrm{~m}$ adalah akuifer bebas, titik Sch-2 pada kedalaman $\geq 5,98 \mathrm{~m}$, akuifer bebas, dan di titik Sch-3 juga akuifer bebas pada kedalaman 15,03 m s/d 20,04 $\mathrm{m}$ dan pada kedalaman $\geq 25,13 \mathrm{~m}$.
\end{abstract}

Kata Kunci: Workshop, metode geolistrik, resistivitas, air tanah, Desa Plana, Banyumas

\section{PENDAHULUAN}

Seiring dengan bertambahnya penduduk, kebutuhan akan air bersih terus meningkat sehingga mengakibatkan cadangan air pada daerah resapan terus berkurang. Pada musim kemarau, banyak daerah di Indonesia mengalami kekeringan karena cadangan air di daerah resapan habis sehingga perlu dicari sumber air yang baru. Salah satu sumber air yang baik digunakan adalah air tanah yang berasal dari proses pendinginan magma dan air yang terperangkap pada saat pengendapan batuan sedimen atau air hujan yang meresap ke dalam tanah. Air tanah tersimpan di dalam lapisan batuan yang disebut akuifer (aquifer). Berdasarkan kedudukannya, air tanah dapat dibedakan menjadi dua jenis, yaitu air tanah dangkal dan air tanah dalam. Air tanah dangkal terletak di dalam akuifer tak tertekan dengan kedalaman hingga $40 \mathrm{~m}$. Sedangkan air tanah dalam yakni air tanah yang tersimpan di dalam akuifer tertekan dengan kedalaman lebih dari $40 \mathrm{~m}$ (Sehah dan Hartono, 2016).

Wilayah Desa Plana Kecamatan Somagede Kabupaten Banyumas merupakan salah satu daerah yang sering mengalami kekurangan air pada musim kemarau. Wilayah desa ini cukup unik, yaitu berbatasan langsung dengan Daerah Aliran Sungai (DAS) Serayu, namun permukaan air sungai tersebut terletak cukup dalam, sehingga air tidak dapat meresap ke pemukiman penduduk. Pada musim penghujan ketika permukaan air Sungai Serayu naik cukup tinggi, justru menyebabkan aliran sungai lain yang masuk atau bermuara ke Sungai Serayu tidak dapat masuk dan meluap ke wilayah di sekitar sungai tersebut dan mengakibatkan banjir. Tujuan kegiatan ini adalah memberikan pemahaman kepada masyarakat tentang jenis dan pembentukan akuifer, menentukan struktur perlapisan batuan bawah permukaan dan mengidentifikasi akuifer berdasarkan hasil survei geolistrik resistivitas konfigurasi Schlumberger.

Eksplorasi air tanah dapat dilakukan dengan menggunakan metode geofisika, yaitu metode geolistrik resistivitas. Sehah dan Hartono (2016) telah melakukan identifikasi akuifer air tanah menggunakan metode geolistrik resistivitas Konfigurasi Wenner di kawasan lahan kritis DAS Serayu di Desa Karangsari dan Penggalang Kecamatan Adipala Kabupaten Cilacap. Penelitian tersebut menghasilkan penampang dua dimensi (2D) yang menunjukkan adanya struktur akuifer air tanah dangkal (shallow aquifer). Akuifer tersebut berupa batuan pasir lempungan dan lempung pasiran 
dengan kedalaman 31,9 m.

Desa Plana memiliki topografi berupa daratan rendah dengan ketinggian $300 \mathrm{~m}$ di atas permukaan laut, sehingga tergolong daratan sedang. Berdasarkan peta geologi lembar Banyumas oleh (Asikin dkk., 1992), Desa Plana tersusun dari formasi batuan aluvium (Qa) yaitu lempung, lanau, pasir, kerikil dan kerakal.

\section{METODE KEGIATAN}

Untuk mencapai tujuan dari kegiatan ini, yaitu meningkatkan pengetahuan tentang jenis akuifer dan melakukan analisis potensi akuifer di Desa Plana, penulis menggunakan metode ceramah dan diskusi interaktif serta workshop metode geolistrik resistivitas.

\section{a. Ceramah dan Diskusi Interaktif}

Kegiatan sosialisasi dan implementasi metode geolistrik resistivitas untuk eksplorasi sumber air tanah adalah ceramah dan diskusi. Kegiatan ini bertujuan untuk meningkatkan pemahaman warga masyarakat tentang proses terbentuknya struktur batuan, jenis akuifer serta metode geofisika resistivitas untuk eksplorasi sumber air tanah. Kegiatan ceramah dan diskusi interaktif menggunakan media audia visual berupa laptop dan LCD proyektor, sehingga materi yang disajikan dalam slide Power Point dan video.

\section{b. Workshop Metode Geolistrik}

Kegiatan workshop atau pembelajaran dan pelatihan metode geolistrik resistivitas untuk eksplorasi sumber air tanah dalam bentuk survei langsung di lapang. Kegiatan workshop mengunakan alat Resistivitymeter Naniura NRD 22 di wilayah Dusun I. Kegiatan workshop meliputi pengukuran dan pengambilan data di lokasi menggunakan Konfigurasi Schlumberger, pengolahan data serta interpretasi, sehingga dihasilkan profil potensi air tanah di Desa Plana. Pengambilan data di tiga titik sounding yaitu Sch-1, Sch-2, dan Sch-3, dengan panjang bentangan masing-masing $200 \mathrm{~m}$. Pengolahan data menggunakan software Microsoft Excell dan Progress v3.0.

Tabel 1. Koordinat titik sounding

\begin{tabular}{|c|c|}
\hline Nama Lintasan & Koordinat \\
\hline Sch-1 & $-7^{\circ} 49^{\prime} 84,52$ " LS dan \\
& $109^{\circ} 36^{\prime} 10,61^{\prime \prime}$ BT \\
\hline Sch-2 & $-7^{\circ} 49^{\prime} 72,36$ " LS dan \\
& $109^{\circ} 36^{\prime} 24,11^{\prime \prime}$ BT \\
\hline Sch-3 & $-7^{\circ} 49^{\prime} 79,45^{\prime \prime}$ LS dan \\
& $109^{\circ} 36^{\prime} 32,76^{\prime \prime}$ BT \\
\hline
\end{tabular}

\section{HASIL DAN PEMBAHASAN}

\section{c. Sosialisasi Metode Geolistrik dan Akuifer Air Tanah}

Sosialisasi merupakan kesempatan untuk melakukan penyebarluasan ilmu pengetahuan dan hasil-hasil penelitian yang telah dilakukan kepada masyarakat. Kegiatan ini juga merupakan salah satu bentuk penyampaian informasi yang berkaitan dengan hasil-hasil penelitian yang selama ini telah dilakukan oleh tim Penelitian Tindakan Berbasis Hasil Riset. Sosialisasi dilakukan dengan metode ceramah dan diskusi interaktif. Pemaparan materi menggunakan Microsoft Power Point dan fasilitas proyektor atau LCD, sehingga dapat ditampilkan berbagai gambar yang berkaitan dengan materi yang disampaikan. Materi dikemas sedemikian sehingga dapat menarik perhatian para peserta sosialisasi. Kegiatan sosialisasi dihadiri oleh perangkat/staff Desa Plana, tokoh masyarakat, serta kelompok mitra, yaitu penyedia jasa pembuatan sumur bor, semuanya berjumlah 33 orang. Tolok ukur ketercapaian pelaksanaan kegiatan sosialisasi adalah adanya peningkatan pemahaman warga masyarakat terkait dengan akuifer dan cara menentukan potensi air tanah menggunakan metode geolistrik resistivitas.

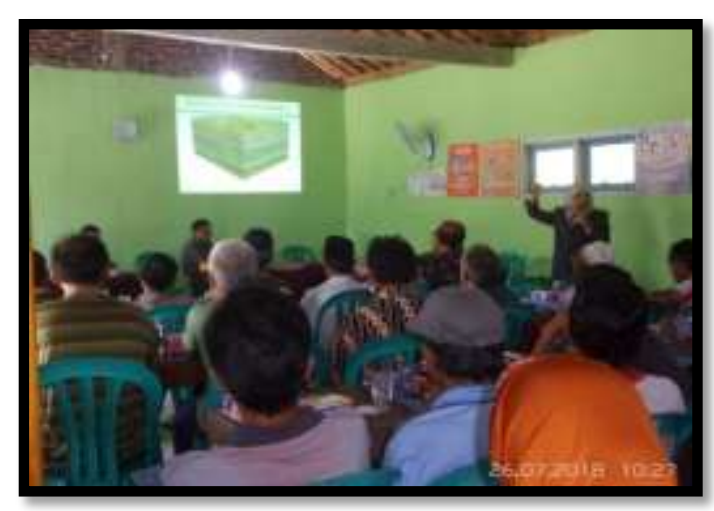

Gambar 1. Pelaksanaan sosialisaisi akuifer

Pada kesempatan sosialisasi juga dilakukan diskusi dengan warga masyarakat berkaitan dengan pemanfaatan metode geolistrik dan akuifer atau lapisan batuan yang dapat menyimpan air tanah. Antusiasme masyarakat, nampak ketika diberi kesempatan untuk mengajuan pertanyaan dan ternyata peserta sosialisasi langsung memanfaatkan kesempatan tersebut untuk mengajukan pertanyaan kepada narasumber. Rincian pertanyaan dan jawaban dari narasumber adalah sebagai berikut :

a. Bapak Yusim (Kepala Desa Plana)

Tanya : Mengapresiasi kepada tim khususnya dan Unsoed, yang sudah memberikan 
pengetahuan dan survey untuk menentukan akuifer di Desa Plana. Berharap hasil survei jika ditemukan ada potensi air tanahnya untuk dibor dan dibuat sumur beserta intalasinya.

Jawab : Program Penelitian dan Pengabdian di Desa Plana merupakan sinergi atau kerjasama antara Unsoed dan Pemerintah Desa Plana. Insya Alloh, jika ada pendanaan lagi pada tahun 2019, di lokasi yang telah disurvei akan dilakukan pengeboran dengan bantuan biaya dari LPPM Unsoed, namun hanya biaya pengeboran saja. Untuk intalasi dan pompa dapat dianggarkan melalui Dana Desa melalui RAPBDes.

b. Bapak Sugeng Prayitno (Ketua BPD Desa Plana) Tanya : Apakah pembuatan sumur bor bisa mengakibatkan dampak negatif seperti yang terjadi di Sidoarjo, keluar lumpur terus menerus.

Jawab : Ada kemungkinan, tetapi sangat kecil karena sumur bor kedalamannya hanya sekitar $100 \mathrm{~m}$. Untuk pengeboran minyak dan gas bumi bisa mencapai kedalaman puluhan kilo meter. Kalau pengeboran untuk sumur air tanah, jika bertepatan dengan lapisan batuan yang dahulunya berupa danau atau rawa, juga bisa terjadi mengelurkan gas, sepeti gas metan.

c. Bapak Sahidin (Tokoh Masyarakat/Staf Pemerintah Desa Plana)

Tanya : 1. Apakah kalau dibuat sumur bor bisa mempengaruhi sumber air di sekitarnya, artinya sumur gali di sekitar sumur bor tersebut menjadi kering

2. Mengapa kalau sumur gali, air sumurnya sering kurang bagus, seperti berwarna kuning (tidak jernih) dan kadang juga berbau.

Jawab : 1. Kalau akuifernya merupakan akuifer dangkal dan terbuka serta dan lapisan batuannya tidak tebal, maka ada kemungkinan dapat mempengaruhi sumur gali yang dekat dengan lokasi sumur bor tersebut.

2. Air yang masuk kedalam sumur gali biasanya merupakan air resapan dari air hujan atau air dari irigasi, sehingga kualitas airnya dipengaruhi oleh kondisi lingkungan di sekitarnya dan kualitas air yang meresap ke sumur gali tersebut.

d. Sdr. Wawan (Mitra/Penyedia Jasa Sumur Bor di Desa Plana)

Sharing atau berbagai pengalaman berdasarkan pengeboran yang telah dilakukan, khususnya di Dusun II, bahwa diperoleh sumber air yang baik dan potensinya cukup besar pada kedalaman lebih dari $60 \mathrm{~m}$, sesuai dengan hasil survei metode geolistrik.

Evaluasi kegiatan melalui kuisioner dibagikan kepada semua peserta yang berjumlah 33 orang. Kuisioner berisi tujuh buah pernyataan yang berhubungan dengan air tanah dan teknik untuk mendapatkan sumber air tanah.

Hasil pengolahan terhadap isian kuisioner seperti ditunjukkan pada Gambar 2. Berdasarkan pada hasil pengolahan kuisioner, masyarakat merasa dapat memahami materi yang disampaikan oleh tim peneliti. Hal ini terlihat pada pernyataan no 1 sampai pada no 4, hampir $100 \%$ masyarakat menyatakan setuju. Hal ini berarti materi yang disampaikan dapat diterima. Sementara untuk pelaksanaan pelatihan survei geolistrik, lebih dari 95\% responden menyetujuinya. Keberadaan sumber air tanah dalam yang biasa disebut dengan akuifer dapat diidentifikasi melalui survei geolistrik resistivitas.

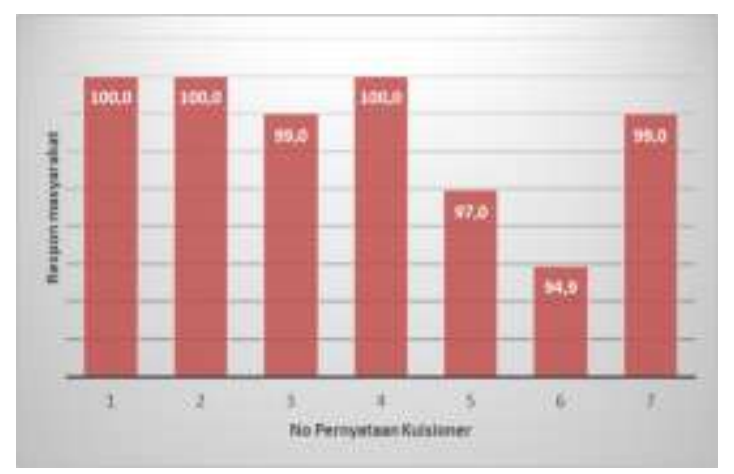

Gambar 2. Indeks capaian antusiasme warga terhadap kegiatan sosialisaisi

\section{d. Workshop Metode Geolistrik}

Workshop atau pelatihan metode geolistrik resistivitas dilakukan di Dusun I Desa Plana. Koordinat titik sounding ditentukan berdasarkan informasi dan saran dari Pemerintah Desa Plana, karena lokasi tersebut disiapkan untuk lokasi sumur atau sumber air bersih Program PAMSIMAS.

Elektroda arus dan elektroda potensial dihubungkan ke Resistivitymeter menggunakan 
kabel penghubung dan sumber arusnya adalah $a c c u$. Selanjutnya melakukan variasi panjang $A B / 2$ yaitu dimulai dari titik $3 \mathrm{~m}$ sampai dengan $10 \mathrm{~m}$ dengan interval sebesar $1 \mathrm{~m}$, untuk titik $10 \mathrm{~m}$ sampai dengan $15 \mathrm{~m}$ diubah dengan interval sebesar $2 \mathrm{~m}$, untuk titik $15 \mathrm{~m}$ sampai dengan $50 \mathrm{~m}$ diubah dengan interval sebesar $5 \mathrm{~m}$, untuk titik $50 \mathrm{~m}$ sampai dengan $60 \mathrm{~m}$ diubah dengan interval sebesar $10 \mathrm{~m}$, untuk titik 60 $\mathrm{m}$ sampai dengan $100 \mathrm{~m}$ diubah dengan interval sebesar $20 \mathrm{~m}$. Untuk variasi $M N / 2$ dimulai dari titik $1 \mathrm{~m}$ yaitu dari $A B / 2$ bernilai $3 \mathrm{~m}$ sampai dengan 15 $\mathrm{m}$. Kemudian nilai $M N / 2$ diubah menjadi $5 \mathrm{~m}$ untuk $A B / 2$ bernilai $15 \mathrm{~m}$ sampai dengan $60 \mathrm{~m}$. Kemudian nilai $M N / 2$ diubah menjadi $20 \mathrm{~m}$ untuk $A B / 2$ bernilai $60 \mathrm{~m}$ sampai dengan $100 \mathrm{~m}$. Lalu nilai arus (I) dan beda potensial $(\Delta V)$ dicatat menggunakan bantuan software Microsoft Excel pada laptop, sekaligus dilakukan Quality Control. Adapun desain survei seperti terdapat pada Gambar 3.

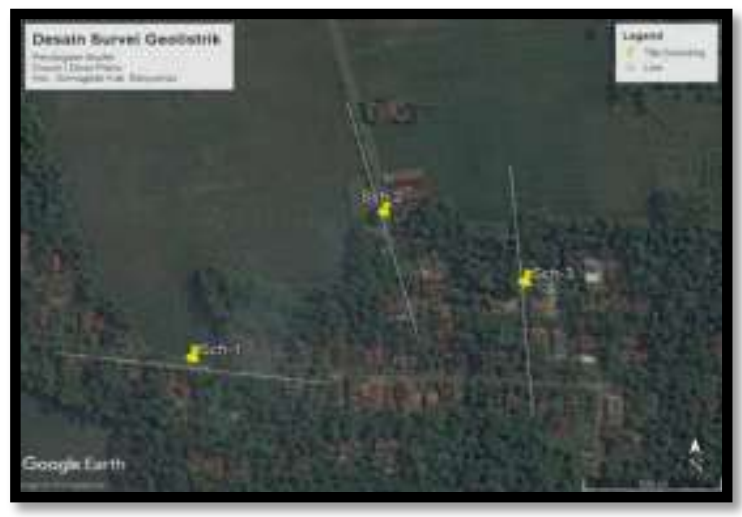

Gambar 3. Desain survei geolistrik di Dusun I Desa Plana

Pengolahan data menggunakan software Progress v.3.0, dengan input data berupa nilai spasi antar elektroda arus $(\mathrm{AB} / 2)$ dan nilai resitivitas semu $\left(\rho_{\mathrm{a}}\right)$ yang diperoleh dari akuisisi data di lapangan. Kemudian melakukan pemodelan sesuai dengan kurva pada software, setelah itu dilakukan inversi. Model Log resistivity hasil inversi 1D pada titik sounding Sch-1, Sch-2 dan Sch-3 menggunakan Progress v.3.0 diperoleh error sebesar 5,84\%, $5,45 \%$ dan $2,75 \%$, seperti ditunjukkan pada Gambar 4, 5 dan 6.

Selanjutnya dilakukan interpretasi untuk mengetahui jenis batuan (lithologi) dan hidrogeologi di titik sounding Sch-1, Sch-2 dan Sch-3. Interpretasi jenis batuan bawah permukaan berdasarkan pada nilai resistivitas batuan dan peta geologi regional wilayah, informasi hasil survei geologi dan referensi dari penelitian sebelumnya. Pada titik sounding Sch-1, lapisan pertama dan lapisan kedua yaitu dengan nilai resistivitas 20,58 $\Omega \mathrm{m}$ dan 366,35 $\Omega \mathrm{m}$ dengan kedalaman $0-6,61 \mathrm{~m}$ merupakan satu jenis lapisan batuan yang sama, yaitu lapisan tanah penutup (top soil).

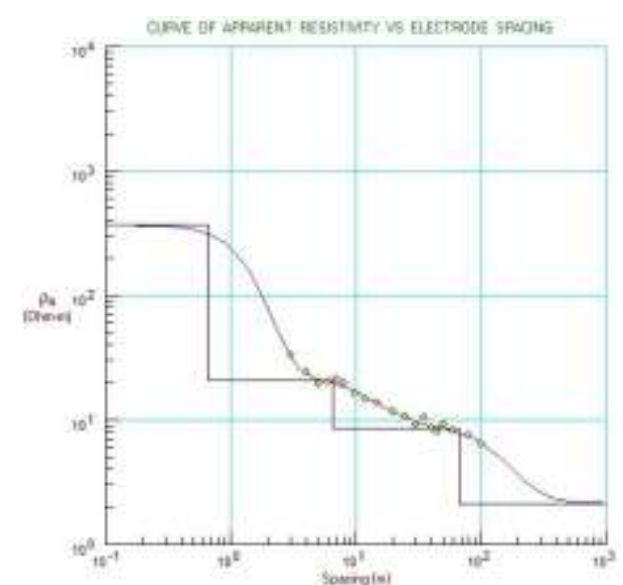

Gambar 4. Kurva log resistivitas titik Sch-1

Lapisan kedua dengan nilai resistivitas sebesar 8,54 $\Omega \mathrm{m}$ pada kedalaman 6,61 - 67,67 m, diinterpretasi sebagai lapisan pasir lempungan. Pasir lempungan merupakan lapisan berupa pasir bercampur dengan lempung, namun pasir lebih dominan. Pasir merupakan lapisan akuifer air tanah paling berpotensi, hal ini dikarenakan pasir memiliki porositas yang relatif kecil yaitu 10-20\% serta mampu menyimpan dan mengalirkan air dengan baik (Sosrodarsono, 2006). Akuifer yang terdapat pada lapisan ini diduga merupakan lapisan akuifer bebas dengan estimasi ketebalan 61,05 m. Hal ini dikarenakan tidak ada lapisan kedap air di atas maupun di bawahnya.

Lapisan ketiga memiliki nilai resistivitas sebesar 2,10 $\Omega \mathrm{m}$ dengan kedalaman $\geq 67,67 \mathrm{~m}$. Lapisan ini diduga sebagai lapisan pasir. Sama halnya dengan lapisan kedua, lapisan ini juga diduga sebagai lapisan akuifer. Namun karena nilai resistivitasnya lebih rendah, maka diduga potensi air yang terkandung pada lapisan ini lebih besar dibandingkan dengan lapisan kedua. Kandungan air pada setiap batuan akan mempengaruhi nilai resistivitasnya. Semakin banyak kandungan air pada suatu batuan maka nilai resistivitasnya semakin kecil begitu pula sebaliknya (Vebrianto, 2016). Hal ini dikarenakan air yang terkandung dalam batuan dianggap sebagai konduktor yang baik. Ketika di aliri arus listrik maka air tersebut akan terurai menjadi ion-ion yang dapat menghantarkan listrik. Lapisan ini merupakan lapisan akuifer bebas. Hal ini dikarenakan tidak ada lapisan kedap air di atas dan di bawahnya. 


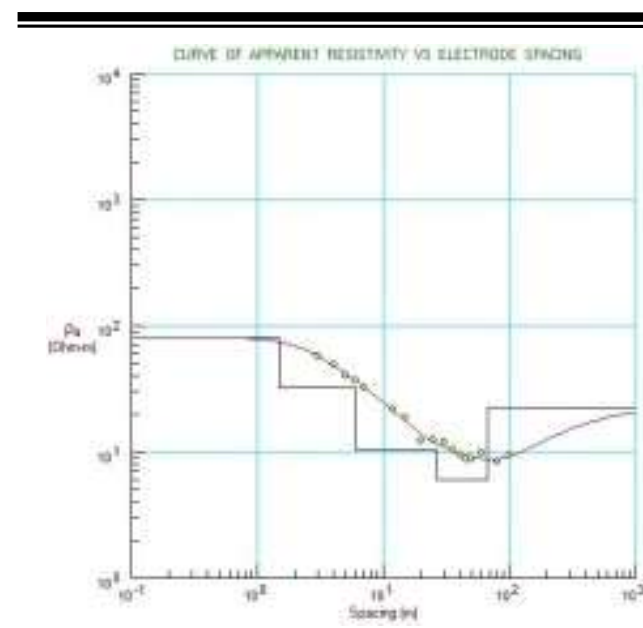

Gambar 5. Kurva log resistivitas titik Sch-2

Berdasarkan hasil pengolahan data pada titik sounding Sch-2 diperoleh 5 lapisan batuan penyusun bawah permukaan (Gambar 5). Namun setelah dilakukan interpretasi, lapisan pertama dan lapisan kedua yaitu pada nilai resistivitas $80,24 \Omega \mathrm{m}$ dan 32,54 $\Omega \mathrm{m}$ dengan kedalaman $0-5,98$ m merupakan satu lapisan, yaitu lapisan tanah penutup (top soil). Berdasarkan penelitian Usman dkk. (2017) pada rentang nilai resistivitas tersebut memiliki lithologi batuan berupa pasir lempungan dan kerikil. Hidrogeologi dari lapisan ini diinterpretasikan sebagai lapisan non akuifer. Lapisan kedua memiliki nilai resistivitas sebesar $10,43 \Omega \mathrm{m}$ dengan kedalaman 5,98 - 26,49 m. Lapisan ini diduga memiliki lithologi batuan berupa pasir lempungan. Berdasarkan penelitian yang dilakukan oleh Rolia (2011) pasir lempungan diinterpretasi sebagai lapisan akuifer bebas. Hal ini dikarenakan tidak ada lapisan kedap air di atas dan dibawahnya. Estimasi ketebalan akuifer bebas pada lapisan ini adalah 20,51 m. Lapisan ketiga memiliki nilai resistivitas sebesar 6,00 $\Omega \mathrm{m}$ dan kedalaman 26,50 - 66,74 m. Lapisan ini diduga sebagai lapisan pasir.

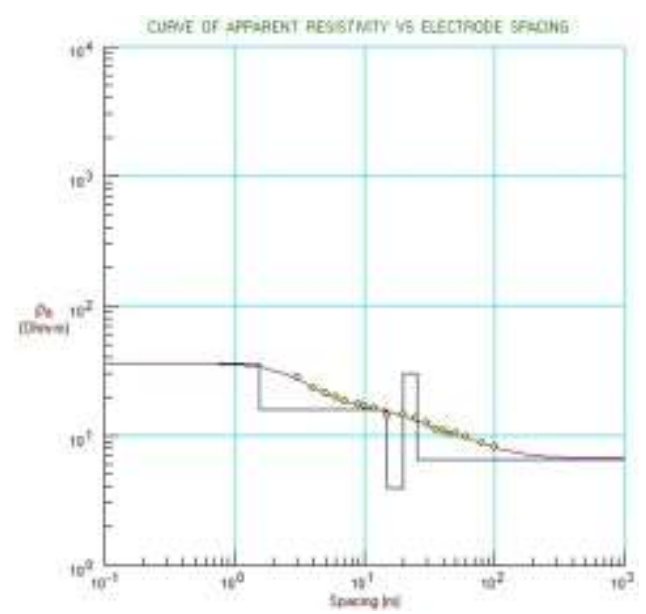

Gambar 6. Kurva log resistivitas titik Sch-3
Berdasarkan hasil pengolahan data pada titik sounding Sch-3 diperoleh 5 lapisan batuan penyusun bawah permukaan (Gambar 6). Lapisan pertama memiliki nilai resistivitas sebesar 36,01 $\Omega \mathrm{m}$ dengan kedalaman $0-1,55 \mathrm{~m}$, merupakan lapisan tanah penutup (top soil). Lapisan ini diduga memilki lithologi batuan berupa pasir lempungan dan kerikil. Hidrogeologi dari lapisan ini diinterpretasikan sebagai lapisan non akuifer.

Lapisan kedua memiliki nilai resistivitas sebesar 16,06 $\Omega \mathrm{m}$ dengan kedalaman 1,56-15,03 m. Lapisan ini diduga memiliki litologi batuan berupa pasir lempungan. Lempung pasiran mempunyai sifat kelulusan air dengan kategori sedang, sehingga pada lapisan lempung pasiran dapat diinterpretasi sebagai akuifer bebas (Darsono dkk., 2012). Estimasi ketebalan akuifer bebas pada lapisan ini adalah 13,46 m. Sedangkan lapisan ketiga memiliki nilai resistivitas sebesar 3,94 $\Omega \mathrm{m}$ dengan kedalaman 15,03 20,05 m. Lapisan ini diduga memiliki litologi batuan berupa pasir. Pasir merupakan lapisan yang baik untuk menyimpan dan meloloskan air tanah. Sehingga lapisan ini diinterpretasi sebagai lapisan akuifer. Akuifer yang terdapat pada lapisan ini merupakan lapisan akuifer bebas. Estimasi ketebalan akuifer bebas pada lapisan ini adalah $13,46 \mathrm{~m}$.

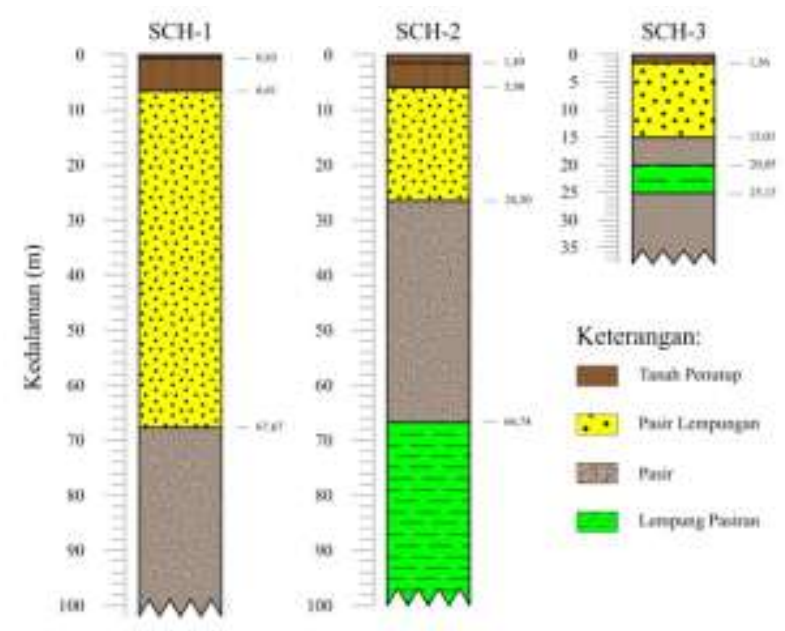

Gambar 7. Interpretasi lithologi di Sch-1, Sch-2 dan Sch3 Desa Plana, Somagede

Lapisan keempat memiliki nilai resistivitas sebesar 30,32 $\Omega \mathrm{m}$ dengan kedalaman 20,05 - 25,13 m. Lapisan ini diduga memiliki lithologi batuan berupa lempung pasiran. Lempung pasiran merupakan lapisan yang dapat menyimpan dan mengalirkan air dalam jumlah terbatas sehingga lapisan ini diinterpretasi sebagai lapisan akuitar. Estimasi ketebalan akuitar pada lapisan ini adalah $5,08 \mathrm{~m}$. Lapisan kelima memiliki nilai resistivitas sebesar $6,63 \Omega \mathrm{m}$ dengan kedalaman $\geq 25,13 \mathrm{~m}$. Lapisan ini diduga memiliki lithologi batuan berupa pasir. Seperti pada lapisan ketiga lapisan ini baik untuk mengalirkan dan menyimpan air tanah. Pada bagian atas lapisan ini terdapat akuitar yang 
menandakan bahwa lapisan di bawahnya merupakan lapisan akuifer semi tertekan. Hasil interpretasi lithologi batuan titik sounding Sch-1,Sch-2 dan Sch3 ditunjukkan pada Gambar 7.

\section{KESIMPULAN}

Berdasarkan kegiatan workshop atau pembelajaran dan pelatihan metode geolistrik resistivitas untuk eksplorasi sumber air tanah di Desa Plana, maka dapat disimpulkan sebagai berikut:

1. Tingkat antusiasme dan partisipasi peserta workshop sangat tinggi, yaitu rata-rata lebih dari $95 \%$.

2. Struktur perlapisan batuan berdasarkan nilai resistivitas di Desa Plana secara umum terdiri dari tanah penutup (top soil), lempung pasiran, pasir lempungan dan pasir.

3. Jenis akuifer yang telah teridentifkasi titik sounding Sch-1 pada kedalaman $\geq 6,61 \mathrm{~m}$ adalah akuifer bebas, titik Sch-2 pada kedalaman $\geq 5,98 \mathrm{~m}$, akuifer bebas, dan di titik Sch-3 juga akuifer bebas pada kedalaman 15,03 $\mathrm{m} \mathrm{s} / \mathrm{d} 20,04 \mathrm{~m}$ dan pada kedalaman $\geq 25,13 \mathrm{~m}$.

\section{REFERENSI}

Asikin, S., Handoyo, A., dan Dharmayuda. 1992. Peta Lembar Geologi Banyumas, Jawa. Bandung: Pusat Penelitian dan Pengembangan Geologi.
Darsono, B. Legowo, dan Darmanto. 2012. Identifikasi Potensi Akuifer Tertekan berdasarkan data Resistivitas Batuan (Kasus : Kecamatan Sambirejo Kabupaten Sragen). Jurnal Fisika FMIPA UNS, Volume 13. No.1, 34-38.

Rolia, E. 2011. Penggunaan Metode Geolistrik Untuk Mendeteksi Keberadaan Air Tanah. Jurnal Tapak. Fakultas Teknik Universitas Muhammadiyah Metro. Vol. 1

Sehah dan Hartono, 2016, Pemanfaatan Metode Resistivitas untuk Mengidentifikasi Akuifer Air Tanah di Kawasan Lahan Kritis Daerah Aliran Sungai (DAS) Serayu Desa Karangsari dan Desa Penggalang Kecamatan Adipala Kabupaten Cilacap. SIMETRI Jurnal Ilmu Fisika Indonesia, Volume 2 No.2, 49-56. HFI Wilayah Barat. Palembang.

Sosrodarsono, S. (Ed). 2006. Hidrologi untuk Pengairan. Jakarta: PT. Pradya Paramita.

Usman, B., Manrulu, R., Nurfalaq, A., dan Rohayu, E. 2017. Identifikasi Akuifer Air Tanah Kota Palopo Menggunakan Metode Geolistrik Tahanan Jenis Konfigurasi Schlumberger. Jurnal Fisika FLUX, Vol. 14, No. 2: 65-72

Vebrianto, S. 2016. Eksplorasi Metode Geolistrik Resistivitas, Polarisasi, Terinduksi, dan Potensial Diri. Malang: UB Press. 